\title{
AGROA-CLIMATIC POTENTIAL ASSESSMENT FOR CROP INTENSIFICATION IN SOUTHERN SRI LANKA - A CASE STUDY IN MATARA DISTRICT
}

\author{
C.M. Navaratne \& K.D.N. Weerasinghe \\ Department of Agricultural Engineering, Faculty of Agriculture, \\ University of Ruhuna
}

The climatic potential in respect $\varphi$ onsel, duration and magnitude of the rainfall werc assessed using the rainfall probability concepts and the climatic water balance approach. The rainfall data for 45 consecutive years ( 950 - 1995) were collected from 10 stations in different agroclimatic regions of Matara district. The limits of $10 \mathrm{~mm}$ weekly rain at $75 \%$ probability and Hargreave's Moisture Ava lability Index of 0.34 in weekly basis were used to deinarcate wet and dry weeks of the area.

The $1^{s 1-} 10^{\text {th }}$ and the $26^{\text {th }}-36^{\text {th }}$ weeks of the calcndar year are recorded as dry wecks in the sclected regions cxcept in Anninkanda. The duration of wet period during Yala and Maha seasons in the selected regions differs from 1 week to 21 wecks and it is closcly related with the mean annual rainfall of the regions. Among all sclected regions, the longest wet period is recorded in Anninkanda whereas the shortest wet period is recorded in Kekanadura and Dandeniya

The onsel of rain in Yala and Maha scasons falls during $9^{\text {th }}-20^{\text {th }}$ and $34^{\text {th }}-40^{\text {th }}$ meteorological weeks respectively in all the selected regions. The carly onset of rain is expected in the locations where the annual rainfall is high. The duration and magnitude of rainfall increase from south to north and from east to west in the district.

Proceedings of the Eighth Anmul Forestry and Environment Symposium 2002 of the Department of Forestry and Environmental Science, University of Sri Jayewardenepura, Sri Lanka 